\title{
Zoning of snowiness and avalanching in the mountains of western Transcaucasia
}

\author{
E. Troshinina, T. Glazovskaya, N. Kondakova, V. Sokolov \\ Laboratory of Snow Avalanches and Mudflows, Faculty of Geography, Moscow State University, Vorobievy Gory, 119899 Moscow, Russia
}

\begin{abstract}
In the mountains of the moist-subtropical zone of western Transcaucasia seven zones of snowiness are distinguished, depending on the heights from sea level to the tops of mountain ranges. Data are taken from 17 years of snow-avalanche observations. In a legend of a map the quantitative characteristic of the avalanching conditions for each zone is given. Interannual variability of snow depth is up to $100 \mathrm{~cm}$ in low mountains and about $600 \mathrm{~cm}$ in the middle belt of mountains. The inversion of snow accumulation is registered. The frequency cycles of heavy-snow (3-4 years) and of especially heavysnow (10-12 years) winters are determined. The avalanche danger is provoked not by the total depth of the snow, but by the stormy snowfalls. The particular conditions of creation and development of nival processes are distinguished here: dry avalanches on the crests of mountains, wet avalanches in the middle mountains and slushflows in the low mountains. Despite low avalanche activity, avalanche risk is high due to the factor of unexpectedness.
\end{abstract}

\section{INTRODUCTION}

A study of the snow-avalanche regime of the mountain regions of western Transcaucasia was conducted covering 17 years and 20 observation points in the mountains located along the boundary of Georgia and Turkey. In this generally high-altitude belt, research of snow accumulation and avalanching circumstances is complicated. Various oroclimatic conditions of the mountainous part of Transcaucasia are used as the basis for evaluating the avalanche regime. With the help of geographic-analytical methods, the specific state of the snow-cover metamorphism was established in this unique, moist-subtropical climatic belt which has no analogues elsewhere in Europe. Similar geographical conditions are perhaps also typical of mountainous regions of Japan, southeast China, the subtropical regions of the Himalayan slopes and the southeast part of North America. The mountain ranges of Adzharia encircle like a horseshoe the coast of the Black Sea and the valley of the Adzharis-Zhali river. The main feature of the climatic conditions is a high mean annual air temperature (at the coast of Batumi, $+14^{\circ}$ to $15^{\circ} \mathrm{C}$ ) with small diurnal and annual variations; in most regions of Adzharia, winters are warm. The subtropical character of the climate persists up to an absolute altitude of 500-700 m, above which lies a zone of rather humid, moderately warm climate. On territory located below $600-700 \mathrm{~m}$ the mean temperature of the coldest month never reaches $0^{\circ} \mathrm{C}$. On the other hand, the mean January temperature on the greater part of the mountainous territory lies between $+2^{\circ}$ and $-2^{\circ} \mathrm{C}$. In the middle mountainous part of western Transcaucasia, above $1000 \mathrm{~m}$ a.s.l., the temperature falls and there is a change to a humid, moderately cold climate (with a short cold winter and a long warm summer). Above 2000-2200 m (upper timberline) there is a zone of humid, alpine (cold) climate with no fullscale summer. The July mean temperature is $+8^{\circ}$ to $10^{\circ} \mathrm{C}$, the January mean temperature is $-8^{\circ}$ to $-12^{\circ} \mathrm{C}$, and the minimum winter temperature can drop to $-20^{\circ}$ to $-25^{\circ} \mathrm{C}$. Even in this zone, however, thaws are frequently observed during winter.

\section{SNOWINESS}

Western Transcaucasia is called "the pole of precipitation and snowiness" due to the amount of precipitation: the annual precipitation is $4015 \mathrm{~mm}$ w.e. (mount Tsiskari, Adzharo-Imeretinski range). In the seaside band and on the mountain slopes facing the sea, the mean annual precipitation is $2300-2800$ $\mathrm{mm}$, in the valleys of internal Adzharia it is $1000-1400 \mathrm{~mm}$ and in the mountains it is $1400-1800 \mathrm{~mm}$. The precipitation is abundant in all seasons, with a maximum during autumn and winter, and is characterized by high intensity. For example, in Batumi the mean annual number of days with precipitation of $>30 \mathrm{~mm}$ equals 27 . The prolonged heavy precipitation promotes formation of floods, mudflows, landslides and snow avalanches. In the cold period (December-May) the amount of precipitation ranges from $1000-1500 \mathrm{~mm}$ in the west to $600-800 \mathrm{~mm}$ in the east. The snowfalls are characterized by long duration (e.g. at $200 \mathrm{~m}$ a. s. $1 ., 99 \mathrm{~h}$; at $1000 \mathrm{~m}$ a.s.l., $100 \mathrm{~h}$; at $2000 \mathrm{~m}$ a.s.l., $115 \mathrm{~h}$ ). They yield a deposition of fresh snow of up to $200 \mathrm{~cm} \mathrm{~d}^{-1}$, the largest value measured in the former Soviet Union. In some anomalous snowy winters the depth of snow along the shores of the Black Sea (in Batumi, Sukhumi) may reach $90-100 \mathrm{~cm}$, but usually only for 2-3 days. The number of days with snow here is up to 20. In the mountains there is so much snow that sometimes its layers can cover $7 \mathrm{~m}$ high trees. When this occurs, it is possible for snow avalanches to glide over the surface located at the level of the tops of the trees. The locations of release of such avalanches are hardly predictable, but such events have been registered in the Caucasus Mountains (Dzhuba, 1980).

Seven snow-avalanche zones are chosen, and the map of their arrangement is composed according to the conditions of snowiness, which basically coincide with high-altitude climatic zones (Fig. 1). In the legend of the map (Table 1) the quantitative characteristic of the avalanching conditions for each zone is given. The probability of formation and duration of a stable snow cover allows two types of winters to be distinguished in western Transcaucasia. The unstable-snow winters 
Table 1. Legend to Figure 1. 1. Dividing line of the belt of the stable-snow-cover winters. 2. Dividing line of the zones with different snowiness. 3. Many large and average-size avalanches, October-May: avalanches from new snow, snow-drift avalanches and wet avalanches. 4. Many large and average-size avalanches, November-April: new-snow avalanches, snowdrift avalanches, slush avalanches. 5. Many small avalanches, December-March: avalanches after heavy snowfalls. 6. Territories without avalanche hazard. 7. Dividing lines of avalanche-hazardous regions. 8. Main wind directions. 9. Range-lines and their heights

Zo of winters with
stable snow cover $\quad$ Depth of snow cover $\quad$ Probability of avalanching

$\mathrm{cm}$

Number of avalanche- Maximum intensity
hazardous snowfalls $\quad$ of snowfalls

$\mathrm{cm} \mathrm{h}^{-1}$

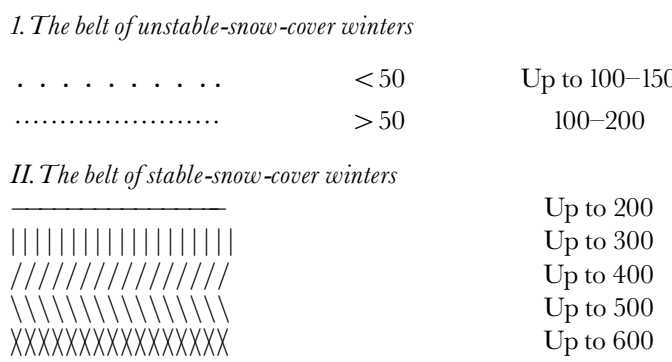

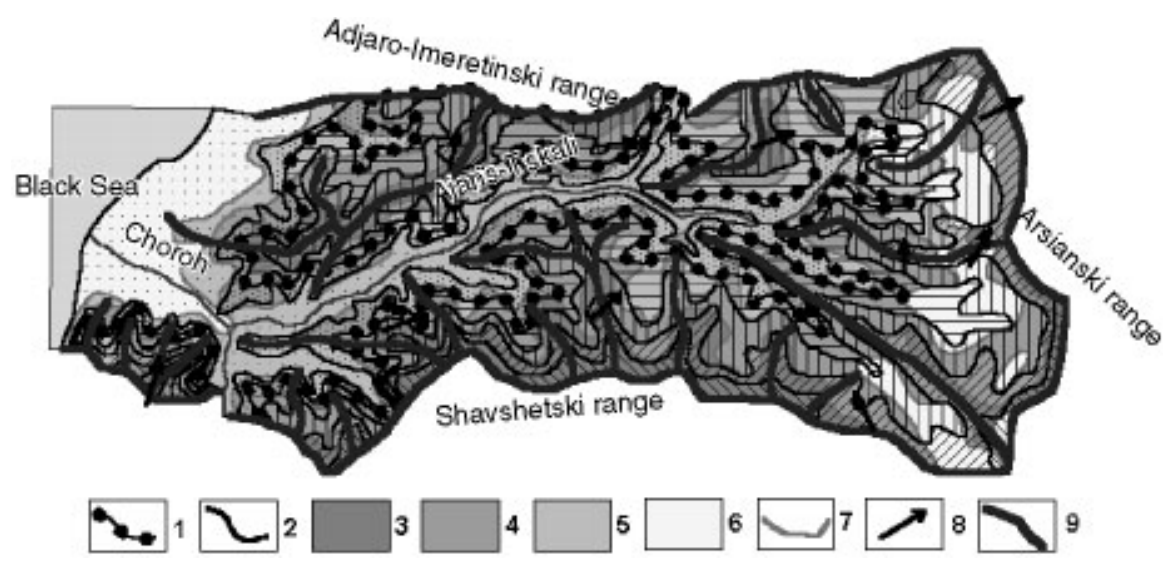

Fig. 1. Snowiness and avalanches in the Adzharis-Zhali river basin. Legend to the map is in Table 1.

are observed in a high-altitude belt up to $1000 \mathrm{~m}$, with a zone of stable-snow winters located above. The depth of the snow cover in some multi-snow years reaches $160 \mathrm{~cm}$. New-snow avalanches are registered even on the mountain slopes near the Black Sea (near Sarpi, Sochi, etc.). Our studies of the snow-avalanche regime of the western Transcaucasian mountains have shown that the related data on the snow-storage value in this region are essentially underestimated. The zone with the deepest snow cover is located at 1500-2000 $\mathrm{m}$ a.s.l. (extremely increased snowiness) (Fig. 2). Western windward slopes and near-ridge sites of eastern leeward slopes are the snowiest. In the forest belt the snow is uniformly accumulated, but on the northern and eastern slopes in the beech woods (1400-1500 m) large drifted snowpatches survive even in summer. During snowfalls in winter, snow avalanches occur even in the forest belt. They move between the trunks of the trees, sliding easily down as powder-snow clouds because of the looseness of the snow cover.

Extraordinary avalanche-hazardous situations arise in mountains during heavy snowfalls. Increase of the snow cover by $>20 \mathrm{~cm} \mathrm{~d}^{-1}$ for several consecutive days is usually accompanied by massive avalanching. The number of such avalanche-hazardous snowfalls in the different high-altitude zones varies from 3 to 17. The number of very heavy snowfalls $\left(40 \mathrm{~cm} \mathrm{~d}^{-1}\right)$ reaches 13 . The total number of snowfalls in heavy-snow winters is generally less than in low-snow winters, but their duration is longer and avalanche potential is increased.

The long-term variability of snowiness has a well-expressed 3-4 year rhythm for the heavy-snow winters, and a 10-12 year cycle for the very heavy-snow winters. The variation of the snow-cover depth in winters of different types is shown in Table 2.

\section{AVALANGHING}

The high snowiness of the mountain regions tells little about the features of avalanching. The peculiarity of the structuralstrength properties of a "subtropical" type of snow cover reflects the processes of the avalanching (Troshkina, 1992). In the middle mountain part of western Transcaucasia, in the zone of stable-snow winters, the snow cover exhibits high strength (up to $10^{3} \mathrm{~kg} \mathrm{~m}^{-2}$ ) due to its rapid compaction under the weight of the overlaying snow and the rather "warm" temperature conditions of the winter period. The frequent thaws and the strong winds during the snowfall promote snow settling. In the high mountains the avalanches mainly form from new and drifted snow during the first hours or first 1-2 days of snowfall. These avalanche types are the most widespread in the study region. They form 


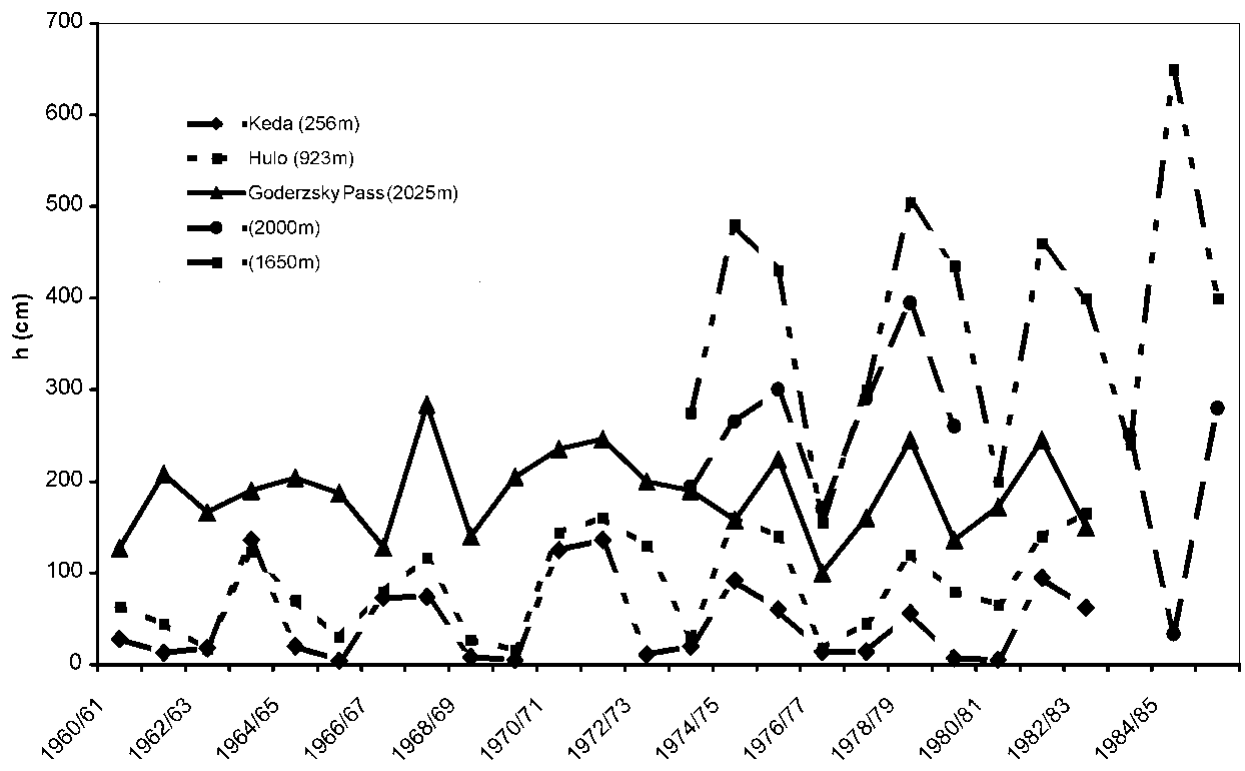

Fig. 2. Variations of the maximum depth of snow cover at different heights in the mountains of Adzharia.

mainly on the eastern and northern slopes. Their volumes do not usually exceed some tens of thousands of cubic meters, but sometimes they reach $10^{6} \mathrm{~m}^{3}$. Such avalanches are frequently accompanied by an airwave. They block the roads and destroy houses and other buildings. Estimating the avalanche danger in these regions is not easy because the avalanche motion is often through the forest. Once a snowfall ceases, clear warm weather usually prevails. This promotes the process of compaction and consolidation of the snow because the air temperature rises to positive or close to positive values and there is heavy solar radiation. In such weather, during the long periods of increasing warmth, wet avalanches are formed from loose snow. Similar avalanches occur when a layer of wet new snow covers wet granular snow; such wetsnow avalanches moving in the lower belt of the mountains down the steep slopes are saturated with thawed waters and often transform to slushflows or snowy mudflows.

Rain in winter in the mountains of the subtropical zone, especially at altitudes below $1300-1500 \mathrm{~m}$, is quite a real event. Wet ground avalanches and snowy mudflows, along with the avalanches from new and drifted snow, are the most widespread and dangerous types of snow catastrophes; their formation generally takes place from November to May, and most of the avalanches usually occur in December-February. The avalanche risk in the zones of unstable snow under conditions of comfortable subtropical landscapes is considerably increased due to the factor of unexpectedness. The warm sea, the beaches, palms, vineyards and blossoming evergreen trees seem far removed from the possibility of cold-storm snowfalls, which occur unexpectedly in heavy-snow winters.

Table 2. Maximum depth of the snow cover $(\mathrm{cm})$

High-altitude belt Low-snow winter Medium-snowwinter Heavy-snow winter

\begin{tabular}{lccc}
\hline Up to $1000 \mathrm{~m}$ & 60 & 90 & 160 \\
$1000-1500 \mathrm{~m}$ & 80 & 180 & 360 \\
$1500-2000 \mathrm{~m}$ & 160 & 240 & 700 \\
$2000 \mathrm{~m}$ & 200 & 250 & 480 \\
\end{tabular}

\section{CONGLUSION}

In summary, the peculiarities of snow cover and avalanching in the mountains of Transcaucasia are as follows:

1. Extreme snowiness of the mountain region; it is one of the most extreme heavy-snow regions in the world.

2. Special geographical conditions of snow avalanching, when the development of the snow cover results in its settling and decreasing avalanche activity. New-snow avalanches predominate during heavy snowfalls.

3. Increased humidity and warm-winter conditions cause the formation of a special type of the nival phenomenon, from dry avalanches on the ridges to wet avalanches in the middle mountain part and slushflows (snowy mudflows) in the lower mountains.

4. Possibility of avalanching in sites on the marine coast of the subtropical zone of the Black Sea.

5. In contrast to other avalanche regions of the former Soviet Union, the avalanche-hazardous period here is of much longer duration than the stable snow cover.

\section{ACKNOWLEDGEMENTS}

This work was supported by the Russian Fund of Basic Researches (projects N 98-05-64920; 00-15-98502).

\section{REFERENCES}

Dzhuba, V.V. 1980. Fiziko-mekhanicheskiye svoistva snega i lavin Adzharskoi ASSR [Physico-mechanical properties of snow and avalanches in Adzharia]. In Sklonovie protsesi (lavini i sely) [Slope processes (avalanches and mudflows) ]. Moscow, Moskovskogo Universiteta, 57-63.

Troshkina, Ye. S. 1992. Lavinnyy rezkim gornykh territoriy SSSR [Avalanche regime in mountains regions of the U.S.S.R.]. Itogi Nauki Tekh., Ser. Glyatsiol. 11. 